\title{
全人工股関節置換術後のドレナージにおける検討
}

\begin{tabular}{|c|c|c|c|c|c|c|}
\hline 大 & 井 & 律 & 子·城 & 戸 & 研 & 二 \\
\hline 田 & 中 & & 浩 · 脇 & 阪 & 敦 & 彦 \\
\hline 斉 & 藤 & 良 & 明·森 & 信 & 謙 & 一 \\
\hline & 合 & 伸 & 也 & & & \\
\hline
\end{tabular}

\section{Efficacy of Postoperative Suction Drainage in Total Hip Arthroplasty}

\author{
Ritsuko Oi, Kenji Kido, Hiroshi Tanaka, \\ Atsuhiko Wakisaka, Yoshiaki Saito, Kenichi Morinobu, \\ and Shinya Kawai \\ Department of Orthopaedic Surgery, School of Medicine, \\ Yamaguchi University, Yamaguchi, Japan
}

The closed suction drainage of wounds after total hip arthroplasty has become an established routine procedure, with the aim of preventing wound hematomas and thereby reducing wound complications and infection.

A prospective evaluation of 40 hips in 39 patients who had undergone total hip arthroplasty was conducted to assess the effect of postoperative suction drainage. No suction drain was placed by randomization in 16 hips.

Statistical analysis of the results showed no statistically significant differences between the drained and undrained group in decrease in hemoglobin, wound healing, and progressive of rehabilitation. We concluded that the use of routine postoperative suction drainage in uncomplicated total hip arthroplasty provides no apparent advantage.

Key words : total hip arthroplasty (全人工股関節置換術), drainage (ドレナージ)

$$
\text { はじめに }
$$

全人工股関節置換術（THA）後に, 創部の血腫を 除去する目的で手術創にドレーンを留置することは広 く行われている. しかし, 最近 THA 後のドレーン留 置は血腫の軽減, 感染率の低下に影響を及ぼさないと 言う報告も散見される ${ }^{1 / 31466}$. 今回当科に扔いても primary THA に対して無作為にドレーンの非留置 を行い，その有効性について検討したので報告する。

\section{対象と方法}

当科にて平成 9 年 5 月から平成 11 年 7 月の間に primary THA を施行した症例のうち, 術前より合
併症を有する症例を除いた 39 例 40 股を対象とした. 男性が 11 股, 女性が 29 股，手術時の年齢は平均 59 才であり, 疾患の内訳は 6 股, 慢性関節りウマチが 7 股，大腿骨頭壊死が 7 股であった。また，七メントを 使用した症例は 23 股，セメントレスは 17 股であり， そのうちドレーンを留置しなかったのは 15 例 16 股で あった（表1）。

出血量, 創治瘉の状態, また術後りハビリテーショ ンの進行度とドレーンの有無との関連性について検討 した，出血量に関してはへモグロビンの变化量を算出 し，創治癒に関しては腫脹や浸出液が著明であったり， 長期に及んだ症例を抽出した。リハビリテーションに 関しては座位, 車椅子移動の開始時期を比較検討した。 


\begin{tabular}{|c|c|c|c|c|}
\hline & & ドレーン非留置 & ドレーン留置 & 合計 \\
\hline \multicolumn{2}{|c|}{ 症例数 } & 15 例 16 股 & 24 例 24 股 & 40 股 \\
\hline \multicolumn{2}{|l|}{ 年齢 } & $59 \pm 18$ 才 & $60 \pm 10$ & 59 \\
\hline \multirow[t]{2}{*}{ 性別 } & 男性 & 7 股 & 4 & 11 \\
\hline & 女性 & 9 & 20 & 29 \\
\hline \multirow[t]{3}{*}{ 疾患 } & $\mathrm{OA}$ & 7 & 19 & 26 \\
\hline & $\mathrm{RA}$ & 4 & 3 & 7 \\
\hline & $\mathrm{AN}$ & 5 & 2 & 7 \\
\hline \multicolumn{2}{|c|}{ セメント } & 9 & 14 & 23 \\
\hline \multicolumn{2}{|c|}{ セメントレス } & 7 & 10 & 17 \\
\hline
\end{tabular}

なお，ドレーンは全例 implant の周囲に留置し，平 均 44.5 時間（24 時間〜 72 時間）で抜去した.

\section{結果}

(1)出血量

ドレーンの非留置群における術中出血量は平均 $625 \mathrm{ml}$ であり,これに対しドレーン留置群では術中 出血量は $643 \mathrm{ml}$ とドレーンからの出血量 $397 \mathrm{ml}$ 合わ せ総出血量は $1040 \mathrm{ml}$ であった（図 1)。両者に扔け る術中出血量には有意差はなかった。

(2)へモグロビン量

術前から術後にかけてへモグロビン量はドレーン非 留置群では $12.1 \mathrm{~g} / \mathrm{dl}$ から $8.5 \mathrm{~g} / \mathrm{dl}$ へ，ドレーン留置 群では $11.6 \mathrm{~g} / \mathrm{dl}$ から $7.5 \mathrm{~g} / \mathrm{dl}$ へと変化していた（図 2)。なお，輸血を行ったものに関してはその量を換算 して術後のへモグロビン量を算出してある.

また，ヘモグロビン変化量はドレーン非留置群では $3.5 \mathrm{~g} / \mathrm{dl}$, ドレーン留置群では $4.1 \mathrm{~g} / \mathrm{dl}$ と両者での有 意差はみとめなかった（図 3 ).

さらにへモグロビン変化量について重回帰分析をお こなったところ，ドレナージの有無を含めて，年齢， 手術時間, 術前のへモグロビン量のうちどの因子も影 響を及ぼしていなかった。

(3)創状態

創の状態に関しては何らかの感染の兆候を示した症 例は無く, ドレーン非留置群で腫脹や浸出液の持続な ど創の小トラブルを認めた症例は 6 例 $38 \%$ であった のに対し，ドレーン留置群では主にドレーン抜去部か らの浸出液の持続などにより 15 例 $67 \%$ と高くなって いた，また，明らかに手術の影響以外の術後合併症を



図 1 術中術後の出血量

(g/dl)

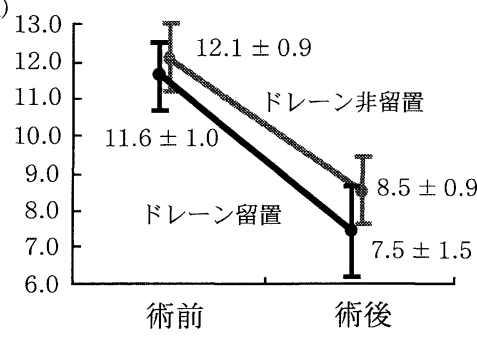

図 2 術前後の $\mathrm{Hb}$ 量

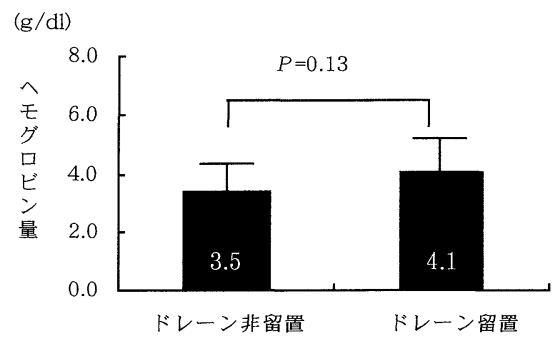

図 3 術前後 $\mathrm{Hb}$ 変化量

表 2 創治癒の状態

\begin{tabular}{lcc}
\hline \hline & ドレーン非留置 & ドレーン留置 \\
\hline 創のトラブル & 6 例 $(38 \%)$ & 15 例 $(67 \%)$ \\
抗生剤追加 & 1 & 4 \\
抜糸時期 & 14.6 日 & 13 \\
\hline
\end{tabular}

除き，発熱や創の状態を勘案して主治医の判断により 内服または点滴による抗生剂追加をおこなった症例は 非留置群で 1 例のみだったが, 留置群では 4 例に認め られた．抜糸の時期に関してはそれぞれ 14.6 日と 13 日であり，ほほ同時期であった（表 2). 


\section{(4)後療法}

術後の座位開始と車椅子使用開始時期は当科では術 後 5〜7日目としているが両者ともほぼ達成されてい た。

\section{考察}

1961 年 Waugh ら ${ }^{81}$ は, 整形外科手術における術後 のドレーン留置の有効性を述べており, 創部での血腫 形成を阻止することで術後の感染や創のトラブルを減 少せし得るとその使用を推奖している。また，彼らは 術後の感染率に関してはドレーンを使用した場合は $1 \%$ であるのに対し，ドレーンを使用しない例では $3 \%$ に上昇したと報告している。 その他，Cruse ${ }^{21} ゃ$ Morris $ら^{51}$ も手術創の合併症, 感染の減少に役立つ とし，ドレナージは術後広く行われてきた。

しかしながらその一方でドレーンを留置することで 起こる逆行性感染の可能性も示唆されている. Rave $ら^{7}$ の報告によると 72 時間留置後の皮膚常在菌の侵 入の頻度は closed suction drainageでは $20 \%$, simple conduit draine 75〜90\%と報告しており, さらにWillettら は drain は48 時間以上留置する ことで手術創の感染率が上昇すると述べている.

最近では，THA 後に関してはドレナージの有用性 は見いだせないとしている報告が多く， Hallstrom

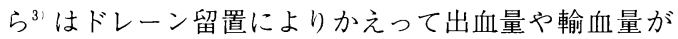
増加すると報告し, Murphy ら ${ }^{61}$ は死腔の血腫はドレー ンでは除去できず, implant 周囲の血腫の大きさは 変わらないと述べている。また, 創治癒, 血腫の程度, 術後の出血量, ヘモグロビン変化量, リハビリテーショ ン, 入院期間のすべてにおいて有意差はなく, 特に留 置の必要性はないと述べている報告は多い息.

今回のわれわれの検討でも術後のへモグロビン変化 量, 創状態など有意差は認められず, THA 後のドレー ンの有用性を見いだすことはできなかった。また，逆 行性の感染に関してはこの調査だけでは十分に検討が
できないが 72 時間留置することで $20 \%$ の細菌侵入が あることを考慮すれば，THAに関しては必ずしも留 置する必要はないのではと考えている.

\section{結語}

(1) THA 後の術後ドレナージの意義について検討し た。

(2)へモグロビン変化量, 創治癒の状態, 術後リハビ リテーションでの両者における有意差は認められなかっ た。

(3) primary THA 後のドレナージは必ずしも必要 ない.

\section{参 考 文 献}

1) Beer, K.J.: The efficacy of suction drains after routine total joint arthroplasty. J Bone Joint Surg, 73A : 584-587, 1991.

2) Cruse, P. J.E., Foord, R.: A five-year prospective study of surgical wounds. Arch Surg, 107 : 206-210, 1973.

3) Hallstrom, B. R., Steel, J. F.: Postoperative course after total hip arthroplasty: wound drainage versus drainage. Orthopaedic review, 21:847-851, 1992.

4) Hadden, W. A., Mcfarlane, A. G.: A comparative study of closed-wound suction drainage vs, no drainage in total hip arthroplasty. J Arthroplasty [suppl] : 21-24, 1990.

5) Morris, A. M.: A controlled trial of closed wound suction drainage in radial masyectomy. $\mathrm{Br} J$ Surg, $60: 357-359,1973$.

6) Murphy, J.P., Scott, J.E.: The effectiveness of suction drainage in totalhip arthroplasty. JR Soc Med, 86 : 388-389, 1993.

7) Raves, J. J., Slifkin, M., Diamond, D. L.: A bacteriologic study comparing closed suction and simple conduit drainage. Am J Surg, 148 : 618-620, 1984.

8) Waugh, T.R., Stinchfield, F.E.: Suction drainage of orthopaedic wound. JBJS, 43 A : 939; 1961.

9) Willett, K. M., Simmons, C. D., Bentley, G.: The effect of suction drains after total hip replacement. JBJS Br, $70: 607-610,1988$. 